Synthesis, part of a Special Feature on Pathways to Resilient Salmon Ecosystems

\title{
Freshwater Ecosystems and Resilience of Pacific Salmon: Habitat Management Based on Natural Variability
}

\author{
$\underline{\text { Peter A. Bisson }}^{1}, \underline{\text { Jason B. Dunham }}^{2}$, and Gordon H. Reeves ${ }^{1}$
}

\begin{abstract}
In spite of numerous habitat restoration programs in fresh waters with an aggregate annual funding of millions of dollars, many populations of Pacific salmon remain significantly imperiled. Habitat restoration strategies that address limited environmental attributes and partial salmon life-history requirements or approaches that attempt to force aquatic habitat to conform to idealized but ecologically unsustainable conditions may partly explain this lack of response. Natural watershed processes generate highly variable environmental conditions and population responses, i.e., multiple life histories, that are often not considered in restoration. Examples from several locations underscore the importance of natural variability to the resilience of Pacific salmon. The implication is that habitat restoration efforts will be more likely to foster salmon resilience if they consider processes that generate and maintain natural variability in fresh water. We identify three specific criteria for management based on natural variability: the capacity of aquatic habitat to recover from disturbance, a range of habitats distributed across stream networks through time sufficient to fulfill the requirements of diverse salmon life histories, and ecological connectivity. In light of these considerations, we discuss current threats to habitat resilience and describe how regulatory and restoration approaches can be modified to better incorporate natural variability.
\end{abstract}

Key Words: Pacific salmon; habitat restoration; watershed processes; natural variation

\section{INTRODUCTION}

The imperilment of many salmon populations is attributed, in large part, to loss of freshwater habitat. Along the Pacific coast of North America, lost or degraded freshwater habitat is identified as a primary contributor to salmon decline more often than any other potential problem, e.g., dams, hatcheries, or overfishing (Nehlsen et al. 1991, National Research Council 1996). Whether habitat is more important than other factors depends on the species and location in question (e.g., Augerot 2005); however, there is broad consensus within the scientific community that the recovery of at-risk salmon cannot be achieved without protecting currently productive freshwater habitat, maintaining watershed processes, and restoring those aquatic ecosystems that have been damaged by human activity (Knudsen et al. 2000, Lackey et al. 2006, Williams 2006). In spite of this widely held belief and the existence of numerous habitat restoration programs with aggregate annual funding of millions of dollars, many populations continue to be significantly imperiled. Two decades after the first distinct population segments of salmon, i.e., evolutionarily significant units or ESUs, were listed in the United States as Threatened or Endangered under the Endangered Species Act, and similarly in Canada under the Species at Risk Act, none has recovered sufficiently to be removed from these lists, and declines continue in many.

The current state of Pacific salmon recovery prompts a simple question: What's missing from current habitat restoration strategies that could help promote resilience? There is no simple answer to this question. We can identify elements missing from management approaches in fresh water that appear inconsistent with current ideas about resilience, but identifying and implementing more effective management actions is a daunting challenge. Other papers in this special feature offer perspectives on areas in which there are consensus and conflict in defining resilience and its role in management of Pacific salmon (e.g., Healey 2009, Waples et al. 2009). From the standpoint of 
freshwater habitat, a useful definition of resilience would vary with the physical or biological system of interest, the environmental context within which it operates, and the spatial and temporal scales under consideration (e.g., Gunderson 2000). Accordingly, a singular definition of resilience for Pacific salmon is perhaps less important from a habitat restoration standpoint than understanding how natural processes have been fundamentally altered by human activities and how those impacts can be reversed to promote salmon recovery.

We examine the importance of natural variability in resilience and the role of three factors that support the productivity of salmon in freshwater ecosystems: the capacity to recover, the diversity of habitats necessary to fulfill life history requirements, and ecological connectivity. Our focus is on a spatial scale that is often called "watershed" by restoration specialists (Bisson et al. 2008), and that roughly corresponds to the term "landscape" as used by ecologists (Fausch et al. 2002, Weins 2002). Finally, we suggest how existing regulatory and management approaches can be retooled to incorporate natural variability in the development of habitat recovery strategies for Pacific salmon.

\section{NATURAL VARIABILITY AND SALMON RESILIENCE}

Salmon populations are highly variable in space and time, and this variability reflects the influences of the highly dynamic environment in which these species evolved (Waples et al. 2008) and that they presently occupy. When annual records several decades long exist, it is not uncommon to observe temporal variability of one to two orders of magnitude in the abundance of a population (Fig. 1). Over multiple decades the signature of climatic cycles begins to appear in patterns of population abundance, with periods of relatively high and low productivity corresponding to broad shifts in the pattern of ocean currents and nutrient upwelling along the Pacific coast (Mantua et al. 1997). Our interest here is on variability over a time frame of years to decades and at the spatial scale of watersheds (Reeves et al. 1995, Rieman et al. 2006).

Managing for resilience in an environment in which ESUs are at risk of extinction will require decisions about habitat that are by necessity relatively short term and geographically focused. These spatial and temporal scales are small relative to the distribution and persistence of Pacific salmon as a whole (Waples et al. 2008), but they are very important for developing management strategies that promote the resilience of ESUs. In addition to temporal trends and cycles, much recent work has emphasized the importance of acute disturbances resulting from events such as wildfire (Rieman and Clayton 1997, Dunham et al. 2007), volcanism (Bisson et al. 2005), and earthquakes (Hastings 2005). Finally, it is important to note that natural variation is expressed differentially over time and space, because watersheds differ in climate, landform, and vegetation, all of which are factors that mediate disturbance and the specific processes that form and maintain freshwater habitat for Pacific salmon (Montgomery 1999, Benda et al. 2004).

Spatial and temporal variability in physical processes is complemented by a remarkable diversity of anadromous life histories in Pacific salmon (Groot and Margolis 1991). For example, some species spend only a few days in fresh water prior to seaward migration, and others spend one or more years in a variety of freshwater environments before migration. Life histories can vary along broad environmental gradients such as from north to south or coastal to interior, and also by sex because males and females face different selective pressures (Groot and Margolis 1991, Hendry and Stearns 2003, Quinn 2005). In populations having extended freshwater residence, multiple life history patterns may exist, but only one or two of them may be favored at any point in time. These may include both anadromous and fully freshwater life histories within the same breeding population (Jonsson and Jonsson 1993). Evolutionary requirements of survival, growth, and reproduction govern the development of life history patterns (Northcote 1978, Hendry and Stearns 2003), but environmental variability leads to certain strategies having better success than others at different times and places. The result is the remarkable variety of life histories we observe in salmon.

This can be illustrated through case studies that show how natural spatial and temporal variability in physical processes and Pacific salmon interact in nature. An often-cited example is provided by Bristol Bay sockeye salmon, whose freshwater habitat remains relatively pristine (Hilborn et al. 2003). For more than a century the relative abundance of sockeye in three major Bristol Bay drainage systems has shifted, with the Naknek- 
Fig. 1. An example of variability in the abundance of a naturally spawning salmon population: the number of chum salmon (Oncorhynchus keta) returning to Fishing Branch River, a tributary of the Porcupine River in British Columbia (graph from Fisheries and Oceans Canada: http://www.taiga.net/ coop/indics/chum.html). The escapement estimates for 1971 and 1975 should be 312,800 and 353,280, respectively.

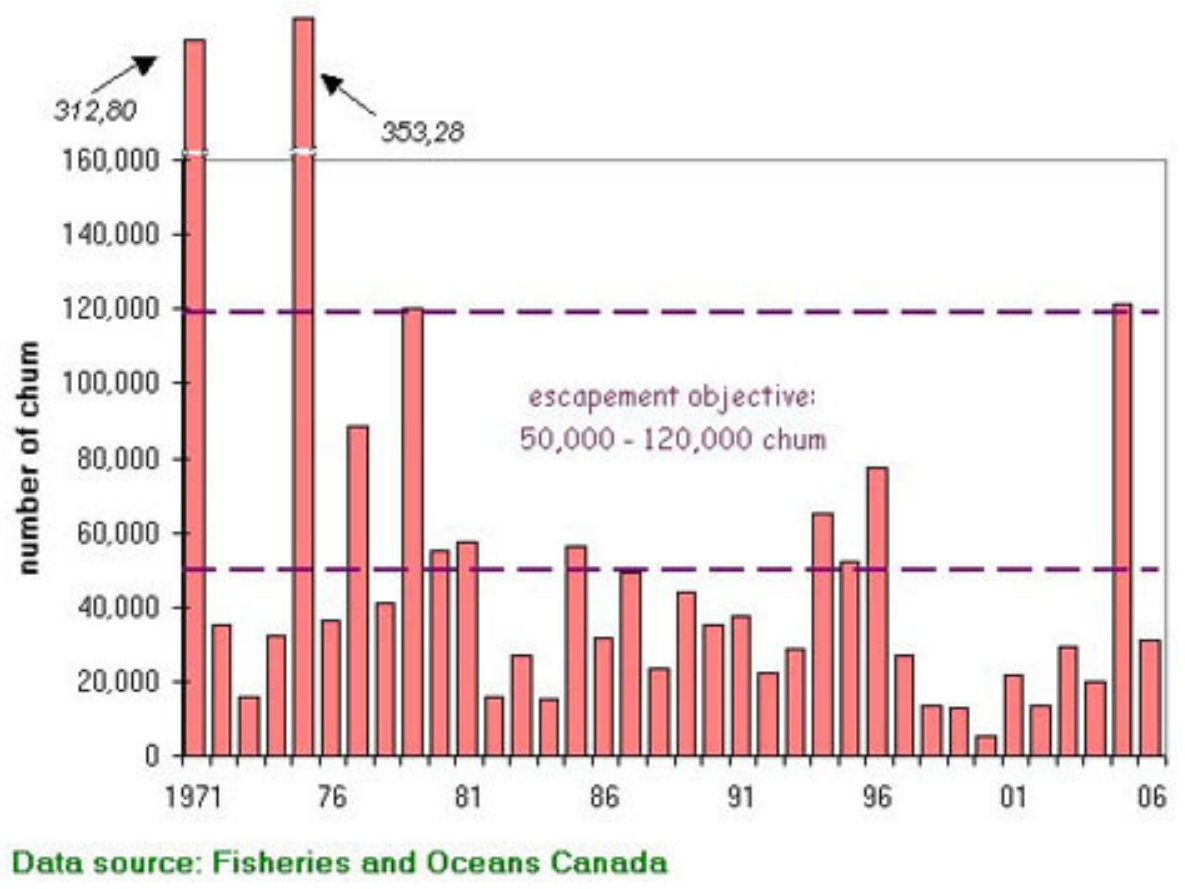

Kvichak and Nushagak drainages producing the majority of fish prior to about 1975, and the Egegik system contributing proportionately more sockeye to the fishery after 1975 (Fig. 2, top right). Productivity declines in the former two drainages have been largely offset by the increased productivity of the latter watershed. A comparison of the number of recruits per spawner (Fig. 2, bottom left) reveals that variation in survival among lake systems has been asynchronous, with some sockeye populations experiencing high survival while others experienced poor survival. Even at the scale of individual populations there has been a shift in favored life histories, with the relative abundance of river- and creek-spawning adults gradually increasing over the past $40 \mathrm{yr}$ at the expense of spawning along lake beaches in the Lake Illiamna system. Hilborn et al. (2003) concluded, "It appears that the resilience of Bristol Bay sockeye is due in large part to the maintenance of all of the diverse life history strategies and geographic locations that comprise the stock. At different times, different geographic regions and different life history strategies have been the major producers."

A second example of the effects of natural variability on Pacific salmon comes from studies of coastal Oregon streams that have experienced infrequent natural disturbances, e.g., wildfires followed by large inputs of sediment and wood from landslides. In these systems, postdisturbance cycles of sediment accumulation and subsequent flushing from watersheds influence habitat diversity, with complex habitats occurring when coarse sediment and large wood are abundant and simplified habitats occurring when these materials are scarce (Reeves et al. 1995). Channels with complex habitat conditions support a greater diversity of salmonid species (Reeves et al. 1993).

Reeves et al. (1995) hypothesized that, in relatively small streams, the cycle of sudden filling and 
Fig. 2. Resilience of a population complex of sockeye salmon in Bristol Bay, Alaska (Hilborn et al. 2003). Upper left: location of fishing districts and major drainage systems. Upper right: total sockeye catch over the last century. Lower left: number of recruits per spawner in each major drainage from 1955 to 1995. Lower right: escapement and proportion of spawning sockeye in Lake Illiamna and its tributaries (copyright U.S. National Academy of Sciences 2003).

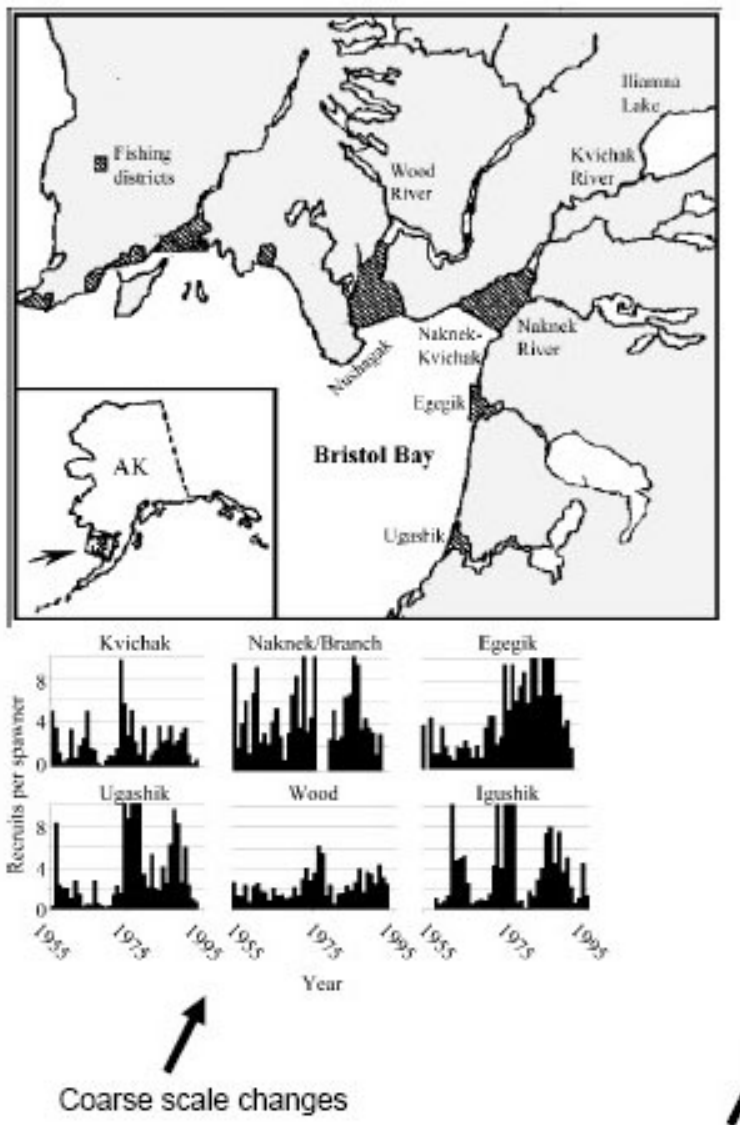

Fine scale changes
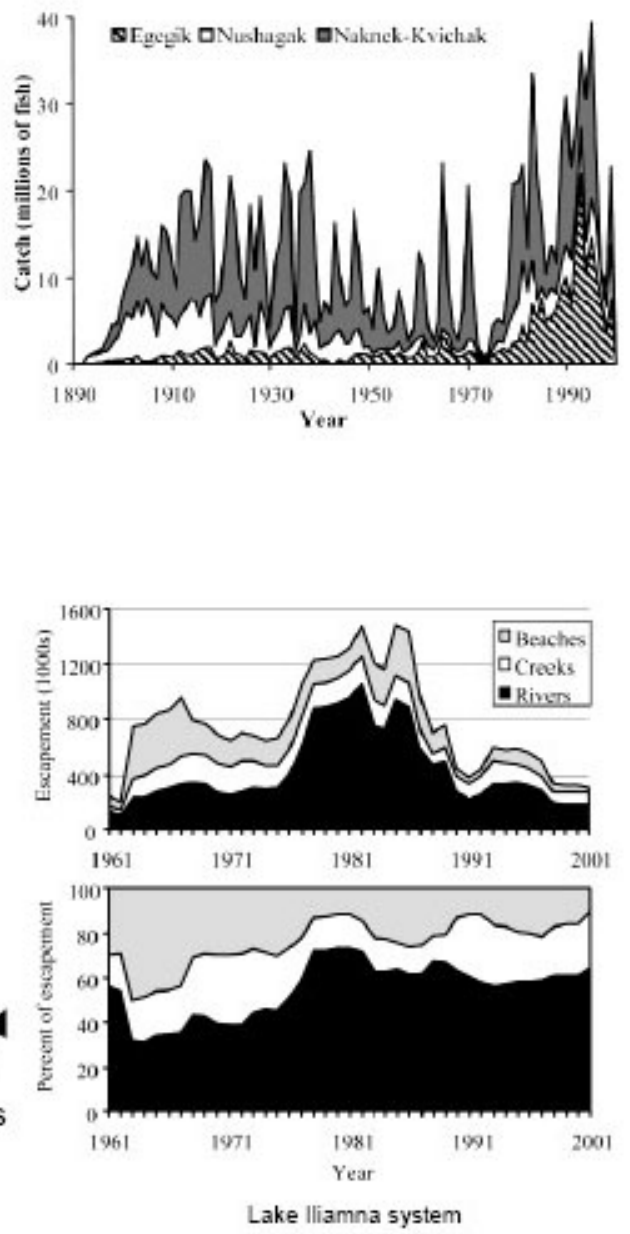

gradual emptying of wood and sediment may occur on a time scale of several hundred years. This longterm dynamic of aquatic habitat following disturbances was modeled by Benda et al. (2004) based on existing sediment budgets and evidence of natural disturbance frequency for coastal salmon streams. They found distinctive sediment loading patterns for channels within a drainage network (Fig. 3). Although headwater streams experience infrequent sediment-related disturbances, the relative magnitude of the disturbance events is high.
Disturbance frequency increases downstream in the drainage network, but the relative magnitude of the sediment change is attenuated. That is, the natural disturbance regime of headwater streams is typified by infrequent but very large, channel-altering events, whereas lowland streams, which integrate the cumulative effects of disturbances over a larger area, tend to be characterized by more frequent disturbances producing fewer changes in habitat features. 
Fig. 3. Sediment loading regimes in small, medium, and large channels over approximately $125 \mathrm{yr}$ (modified from Benda et al. 2004). The smaller graphs at each location show the frequency distribution of sediment depths over the period of simulation.

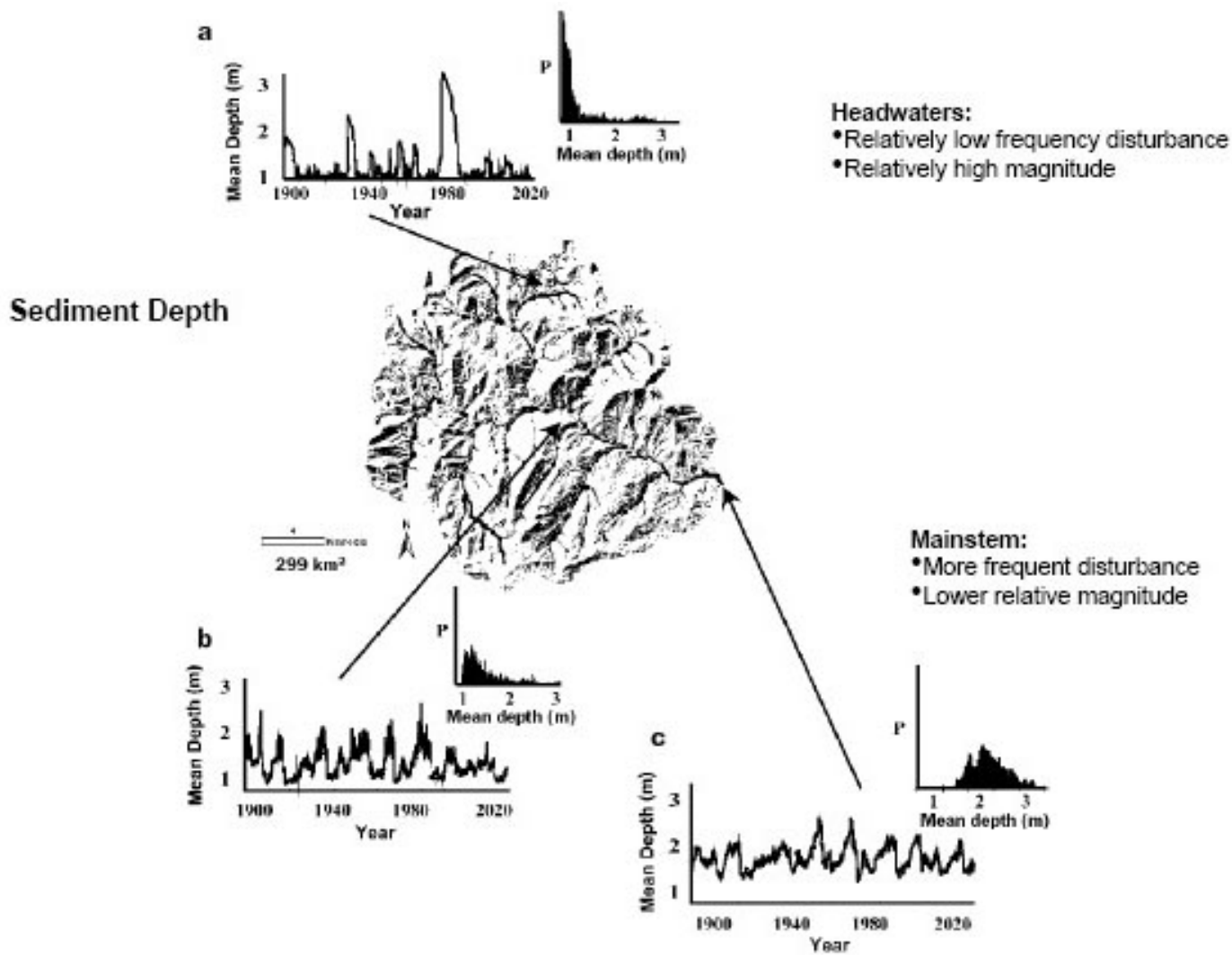

The examples above show how spatial variability in natural processes can strongly influence the productivity of Pacific salmon over time, as observed when data are available or inferred indirectly from cycles of habitat suitability. These examples also point to the importance of life history variability to the resilience of salmonids in dynamic environments (Rieman and Dunham 2000). Evidence from this work suggests three important elements necessary for resilience of Pacific salmon in fresh water: (1) the capacity to recover, (2) the diversity of habitats necessary to support the range of salmon life histories, and (3) connectivity.

\section{Capacity to recover}

The resilience of Pacific salmon is influenced by watershed processes that supply structural components of the aquatic environment such as coarse sediment and large wood, as well as those that support the transfer of energy and nutrients through aquatic food webs. These processes are linked to riparian forests and to forests in upland portions of the watershed that may erode and contribute large trees and coarse sediment to streams. Considerable regulatory attention has been given to riparian forest protection, largely to preserve trees for stream shading and stream-bank stabilization and as future sources of large wood for fish habitat (Bisson et al. 2006). Contemporary forest practices typically restrict harvest in riparian zones but are often less focused on the importance 
of wood recruitment from uplands. In some locations, wood recruited to channels from landslides can constitute a significant portion of the wood load in the stream network (May and Gresswell 2003), and redistribution of hillslopederived wood through fluvial transport is an important process in habitat formation downstream (Benda et al. 2003).

Resilience in Pacific salmon is also tied to the recovery of aquatic and riparian food webs (Bisson and Bilby 1998, Naiman et al. 2002). For example, some projects have attempted to improve freshwater productivity by placing salmon carcasses in streams to restore an important annual source of marinederived nutrients in areas in which salmon runs are depleted (Stockner 2003, Wilzbach et al. 2005). Managing tree species composition in riparian zones can also influence aquatic food webs. For example, conifers in riparian zones may be important contributors of large wood (see above), but smaller deciduous species such as nitrogenfixing alders (Alnus spp.) can deliver more energy and nutrients to streams (Karlsson et al. 2005). Most efforts to improve food-web productivity for salmon are based on the assumption that trophic support from lower to higher consumer levels, with salmon as apex predators, is important. However, in many aquatic ecosystems, consumer-regulated, i.e., topdown, food-web dynamics have received inadequate attention (Power and Dietrich 2002). In Pacific salmon streams and lakes, other top predators are often present, and even terrestrial consumers may play an important role in regulating food-web dynamics (Baxter et al. 2005). A better understanding of the processes influencing the food webs of the aquatic ecosystems that support Pacific salmon is needed, because food resources and the presence of competitors and predators will exert a strong influence on population resilience.

\section{Habitat diversity}

The examples of sockeye salmon resilience in Bristol Bay (Hilborn et al. 2003) and the dynamics of disturbance and freshwater habitats in the Oregon Coast Range (Reeves et al. 1995, Benda et al. 2004) highlight the influence of network dynamics on salmon life histories. Other spatial considerations influencing habitat diversity and resilience have been identified, including habitat complementation, neighborhood effects, habitat supplementation, and source-sink dynamics (Schlosser 1995, Dunning et al. 2002), all of which appear to be important for understanding how Pacific salmon respond to dynamic freshwater environments.

Pacific salmon can require many different habitats in fresh water (Groot and Margolis 1991), including those used for egg incubation, juvenile rearing, and migration of adults (Kocik and Ferreri 1998, White and Rahel 2008). In some cases, the value of a particular location may not be obvious, as in the case of localized thermal refugia (Torgersen et al. 1999, Ebersole et al. 2003) or the use of ephemeral streams (Wigington et al. 2006). Neighborhood effects may also be important; for example, the use of a specific location may be related more to the use of nearby habitats than to the characteristics of the habitat itself (Isaak et al. 2007, Mull and Wilzbach 2007). Habitat supplementation refers to redundancy in terms of multiple habitats that can provide the same function for fish (Moyle and Sato 1991, Schlosser 1995). The importance of supplementation was illustrated in the recovery of Pacific salmon in the wake of the Mt. St. Helens eruption (Leider 1989, Bisson et al. 2005), when salmon occupied alternative habitats after historically used habitats were temporarily destroyed. At a larger spatial extent, metapopulation dynamics such as sourcesink relationships may be important factors in habitat use (Schtickzelle and Quinn 2007), but often the distinction between these and other spatial processes such as those described above is unclear (Rieman and Dunham 2000). In a general sense, however, habitat diversity appears to be essential for supporting Pacific salmon. Understanding more specifically how watershed processes influence population resilience and expression of life histories remains an important information need.

\section{Connectivity}

The role of physical and biotic connectivity in freshwater ecosystems is widely acknowledged to be essential for maintaining habitat dynamics and species responses (Lowe et al. 2006). For Pacific salmon, the importance of movement to fulfill lifecycle requirements is a hallmark of the species' biology. In fresh water, connectivity includes migratory pathways along rivers and their tributary systems as well as unimpeded lateral connections between main channels, secondary channels, and floodplains. Ecological connectivity is similarly critical for processes essential to the function of freshwater ecosystems, including a wide variety of 
complex aquatic and terrestrial interactions that regulate channel dynamics, food webs, and water quality (e.g., Naiman and Bilby 1998, Power and Dietrich 2002). Riparian forests on valley floors and on alluvial terraces adjacent to stream channels play an important role in the dynamics of the water table beneath and adjacent to streams, in moderating discharge during flow extremes, in controlling the concentration of soluble nutrients, in mediating the seasonal input of organic matter and terrestrial food items to aquatic ecosystems, and in regulating microclimate (Naiman et al. 2005, Richardson et al. 2005). Removing barriers to movement and improving natural linkages between terrestrial and aquatic ecosystem processes to re-create normative riverine conditions has become an important conceptual foundation for salmon restoration programs (Williams et al. 2006).

\section{NATURAL VARIABILITY AND MANAGEMENT STRATEGIES}

In a management context, the idea of protecting or restoring natural processes appeals to conventional wisdom. Many view the importance of natural processes as self-evident because Pacific salmon were much more abundant historically than they are today. In spite of this, habitat managers have not been able to fully implement the concept of protecting and restoring natural processes in fresh water. We believe this is because of several factors, including the unrealistic expectation that habitat capacity should be constant and productive over time, the imposition of standards and regulations that ignore natural variability, mismatches between restoration actions and the scale over which natural processes operate, and the challenges posed by unavoidable environmental trends.

\section{Habitat optimization}

The notion that there is a certain suite of habitat conditions that are optimal for salmon owes its genesis in part to studies of fish in pristine watersheds with old-growth forests (Reeves and Bisson 2008). We are aware of no evidence supporting the notion that a single optimum habitat configuration exists that will sustain maximum freshwater salmon production, or that such an ideal state could even persist in dynamic environments. From a management standpoint, the risk is that attempting to engineer aquatic habitats to conform to an idealized condition could result in the loss of the complexity necessary to support various freshwater life-history stages of salmon and other aquatic organisms. This is not to argue that bioengineering has no place in the management toolbox. Engineered habitats may be needed to protect other aquatic and terrestrial resources, or to replace certain habitat types that have been irretrievably lost or substantially altered by human activity. However, projects whose principal objective is to create permanent habitat structures thought to be optimum for salmon will probably address only a limited portion of the habitat needs throughout the life cycle of the target species (Sedell and Beschta 1991), and in any case are likely to require frequent, expensive maintenance.

Another way in which management policies have attempted to optimize aquatic habitats has been through the imposition of fixed environmental standards (Bisson et al. 1997). Many standards began as hazard thresholds that were codified into federal and state water-quality laws after passage of the Clean Water Act and various state-level landand water-use laws (Poole et al. 2004). The putative thresholds represented conditions beyond which further anthropogenic habitat degradation would lead to direct or indirect harm to aquatic life. When the first salmon populations were listed under the Endangered Species Act, environmental standards started to shift from hazard thresholds beyond which survival and reproduction declined to habitat targets that were believed to represent optimum or nearoptimum conditions.

An example of the new emphasis was a matrix of pathways and indicators developed by the National Marine Fisheries Service to assess the functioning of streams and their watersheds as a tool for salmon recovery planning (National Marine Fisheries Service 1999). The matrix identified numerical habitat targets, such as the number of pieces of large wood per unit length of stream, which were considered necessary for a productive ecosystem. However, as pointed out by several of this agency's own scientists, the validity of the relationships between many of the parameters in the matrix and salmon populations remain unverified (Good et al. 2003). These authors argued against co-opting a tool from the regulatory realm for use in recovery planning.

Using fixed habitat standards as environmental targets potentially diminishes the range of 
conditions that occur in a watershed, resulting in a loss of habitat diversity. We illustrate this with conceptual diagrams in Fig. 4. The natural range of a particular habitat feature, e.g., large wood abundance, is illustrated in the upper left graph, in which the distribution of values for that feature in a largely pristine watershed might approximate a bellshaped curve with a relatively wide range (e.g., see Fox 2001). A watershed that has been highly altered by human activity or a severe environmental disturbance (Fig. 4, upper right) is likely to possess a strongly skewed distribution for the same feature, reflecting a large number of locations in the watershed in which the abundance of that particular habitat element has changed in response to a variety of anthropogenic and natural factors. The imposition of a fixed habitat standard essentially forces a universal target on the system (Fig. 4, lower left). Although the target matches the median state of the habitat element in the pristine watershed, management actions will attempt to restore depleted areas to the target state and will allow locations with an abundance of the element to dwindle to the same target level. The median will be restored, but the range of conditions will be truncated. Fully recovering the natural range of states of the habitat element in an altered watershed (Fig. 4, lower right) requires management actions that facilitate restoration of both the median and environmental extremes; otherwise, habitat diversity will be lost (Poole et al. 2004).

The focus on narrow environmental thresholds can come at the expense of recognizing the ecological processes that create and maintain the freshwater habitats of Pacific salmon (Beechie and Bolton 1999) and the ecological context in which they evolved (Frissell et al. 1997). Holling and Meffe (1996) referred to the setting of fixed environmental thresholds as an example of a "command and control approach" to natural resource management. This approach fails when it is applied to systems that are complex, nonlinear, and poorly understood, such as watersheds containing the habitat of Pacific salmon, and it leads to continued loss of resiliency (Dale et al. 2000, Rieman et al 2006).

\section{Inconsistent legal requirements}

Whereas many regulatory requirements and management practices can promote the homogenization of habitats within networks, at a regional scale inconsistent legal requirements can lead to the development of a large patchwork of environmental discontinuities. Environmental laws regulating human activities in and around aquatic ecosystems vary according to type of ownership and predominant land use (National Research Council 1996). Protection requirements for riparian zones, for example, differ when forestry rather than agriculture is the major land use. Even within a particular type of land use, aquatic and riparian protection standards vary according to whether a site is on federal, state, or private property.

The application of different environmental protection policies results in an uneven level of concern for many of the factors important to habitat resiliency. In some watersheds, the importance of riparian forests and floodplains for sustaining resilient salmon habitats is acknowledged explicitly, but in other areas rivers are treated as little more than conduits for water, and the inundation of floodplains may be actively resisted. Nearly all salmon populations spawn and rear in watersheds with multiple ownerships, and variation in the level of environmental protection is problematic if critical habitat requirements are not satisfied.

The Coastal Landscape Analysis and Modeling Study, an analysis of vegetation conditions in western Oregon under different land-use scenarios, provides an example of current land-use fragmentation (Spies et al. 2007). In Fig. 5, the distribution of federal, state, and industrial and nonindustrial private forest lands, as well as lands classified as nonforested with predominantly agricultural and other uses, is plotted to show the fragmented pattern that emerges at the regional scale. Federally managed forest lands conform to the most stringent aquatic protection requirements, followed by state forests, private industrial forests, private nonindustrial forests, and finally nonforested lands. Many of the most important sites for salmon production are located in the lowland areas that receive the least riparian protection (Burnett et al. 2007, Spies et al. 2007). Exposing the populations that inhabit them to continuing habitat degradation will lead to a gradual loss of resiliency, even if headwater areas are well protected. 
Fig. 4. Hypothetical frequency distribution of a habitat element in a pristine watershed (upper left), a highly altered watershed (upper right), a watershed in which a fixed habitat standard has been applied (lower left), and a watershed in which the emphasis has been to restore both the median and natural range of conditions (lower right). The curves represent the distribution of values such as abundance, concentration, or some other metric at various locations throughout the watershed.
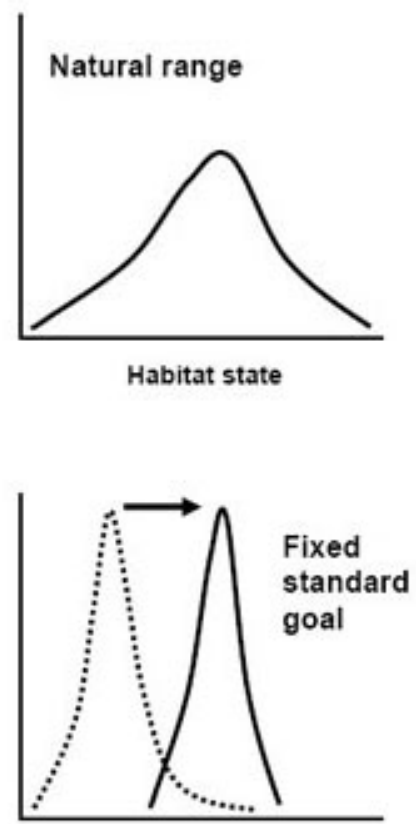

Habitat state
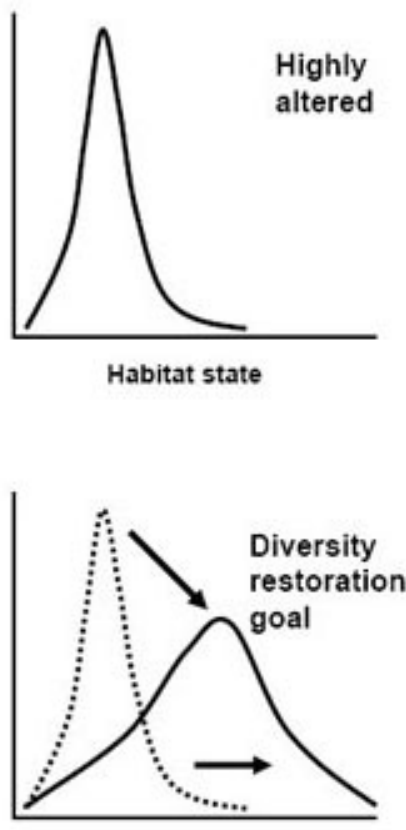

Habitat state

\section{FUTURE TRENDS IN NATURAL VARIABILITY}

The importance of natural variability to the resilience of Pacific salmon is intuitively appealing and supported by a growing body of evidence. At the same time it is clear that changes acting on freshwater ecosystems fundamentally alter watershed processes and variability. Among the many important factors are increased urbanization (Guzy et al. 2008), contaminants (Johnson et al. 2007, Landers et al. 2008), climate change, and invasions of non-native species. Here we focus on the impacts of the latter two changes, because these potentially affect the natural processes discussed in this paper over broad scales.

\section{Climate change}

Climate change is now accepted as a widespread threat to freshwater ecosystems (Poff et al. 2002) and particularly to Pacific salmon (Mote et al.2003). A recent review of the effects of climate change on salmon in the Columbia River Basin (ISAB 2007) summarized the probable consequences along the Pacific coast of North America, including: (1) warmer air temperatures resulting in more precipitation falling as rain rather than snow, (2) diminished snow pack and altered timing of stream flows, (3) increased peak flows in streams, and (4) increases in water temperatures. Not all of these anticipated trends are necessarily harmful to aquatic habitat, and many pale in comparison to other anthropogenic factors, but they do have implications for salmon resilience. 
Fig. 5. The highly complex pattern of land ownership on the Coast Range physiographic province of Oregon (Spies et al. 2007). Legend abbreviations: USFS = U.S. Forest Service, BLM = Bureau of Land Management, State $=$ Oregon State Forests, FI = private industrial forests, NIP = nonindustrial private forests, Nonforest $=$ lands zoned for nonforestry uses.

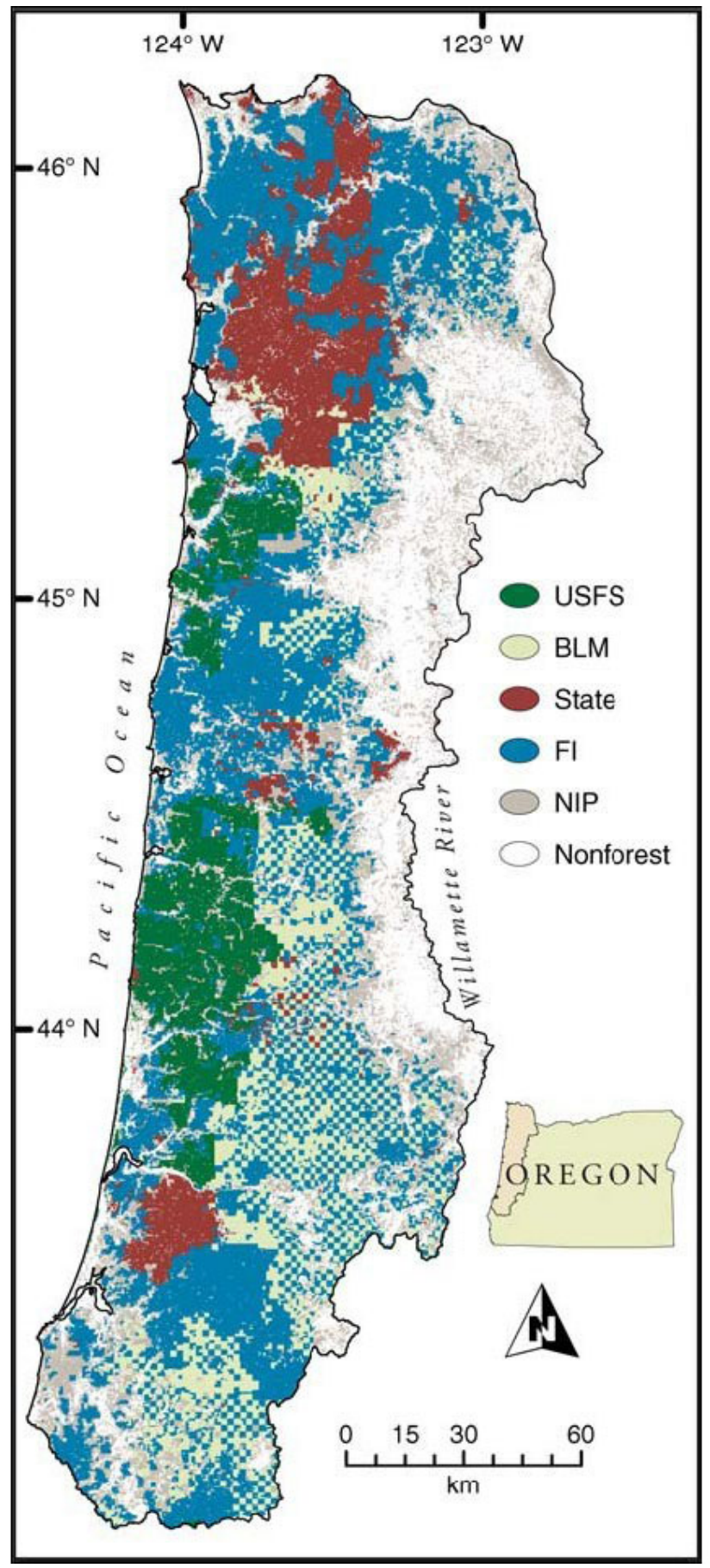


Climate change poses a long list of challenges for maintaining the resilience of Pacific salmon (e.g., ISAB 2007). Perhaps the most obvious management strategy to strengthen resilience in the face of climate change is to maintain as much water as possible in streams and lakes during periods of low flow. Decreased summer low flows may diminish the network of perennial streams, requiring fish to occupy smaller and less diverse habitats (Battin et al. 2006). Lower stream flows during summer may also result in stressful maximum temperatures for Pacific salmon, including migrating adults prior to spawning. The maintenance or restoration of natural processes that moderate stream temperatures, such as promoting the recovery of natural riparian vegetation or eliminating water withdrawals from hyporheic channels (Beschta et al. 1987), may counter some of the undesirable influences of climate change. During the winter, increased flooding may create societal pressure to prevent damage to homes and infrastructure and isolate rivers from their floodplains, but such actions often run counter to the objective of maintaining floodplain processes and aquatic habitat diversity (Greene et al. 2005). Accordingly, assessments to determine where flooding can be allowed in a watershed and, in particular, where flooding will reconnect the river with floodplain habitats are of direct importance to salmon (Hulse and Gregory 2004).

Climate change is often accompanied by the increased threat of invasions by non-native species, which may be well adapted to climate-mediated change (Moyle and Light 1996, Rahel and Olden 2008). In some large rivers in the Pacific Northwest, non-native species have come to dominate fish assemblages, e.g., in the Columbia River (Li et al. 1987), and have largely replaced the role of native fishes within riverine food webs. Most non-native fishes have been deliberately introduced for recreational angling. Equally pervasive, but somewhat less studied, has been the invasion of riparian areas by non-native trees and shrubs (Heckman 1999, Boersma et al. 2006). Very little is known of the effects of invasive riparian plants on the water quality and physical habitat of streams inhabited by Pacific salmon. Moreover, the effects of exotic riparian plants on the contribution of terrestrial organic materials to aquatic ecosystems have rarely been studied.

\section{Invasions of non-native species}

Many of the more notorious invasive aquatic invertebrates in North America, such as the New Zealand mudsnail (Potamopyrgus antipodarum) and the zebra and quagga mussels (Dreissena sp.), have made minor inroads into Pacific salmon streams but are generally not believed to limit recovery potential at present. Given the likelihood that these species or others yet unknown may invade watersheds supporting salmon, it is critical to adopt a forward-thinking approach that restores or maintains natural variability to benefit native species and discourage future invasions. Preventing invasions and eradicating established non-native species presents significant challenges to aquatic ecologists. Minimizing or reversing the conversion of complex riverine habitats, i.e., geomorphically diverse channels with riparian zones containing natural plant communities, to simplified environments, i.e., straightened channels with a reduced riparian zone, often isolated from the floodplain, should help curb the incidence of invasion. This is likely because (1) robust assemblages of native fishes may be better able to resist non-native invaders than native fish communities whose populations are depleted and (2) unnatural alteration of aquatic and riparian conditions may, by chance, highly favor some exotic species. We view the potential success or failure of non-native species invasions to be strongly influenced by natural environmental variability and the presence of conditions that benefit native species.

\section{CONCLUSIONS}

The conceptual basis of aquatic ecosystem science is shifting from an equilibrium perspective to one that recognizes dynamic nonequilibrium conditions and natural variability (Naiman et al. 1992, Wellington et al. 2005). For example, restoration programs in coastal estuaries inhabited by Pacific salmon often acknowledge the importance of reestablishing dynamic physical and biological processes (Simenstad and Cordell 2000). We believe that a dynamic view of aquatic ecosystems requires an increased appreciation of infrequent but large events such as physical disturbances, e.g., storms, fires, and floods, that create and maintain habitats (Reeves et al. 1995, Benda and Dunne 1997, Poff et al. 1997). This perspective recognizes disturbance and successional processes that do not occur in an orderly or predictable manner (Pahl- 
Wostl 1995). Within an area affected by a natural disturbance, several transitional states may be expressed over time, such that the timing or duration of any particular state may be difficult to predict (Wondzell et al. 2007). Succession from one state to another can occur slowly in response to geomorphic adjustments, e.g., elevation change by an earthquake, or more rapidly in response to large, infrequent events such as floods, fires, and landslides. The signature and legacy of these events can influence local conditions for long time periods (Foster et al. 1998). Stream conditions can be viewed as transitory, reflecting local spatial controls, past natural disturbance, and land-use impacts.

Management of the freshwater habitat of Pacific salmon should focus on natural processes and variability rather than attempt to maintain or engineer a desired set of conditions through time (Lugo et al. 1999, Dale et al. 2000). This does not imply that we should attempt to re-create or reestablish completely pristine conditions everywhere, which would simply not be possible. When applied to the management of aquatic ecosystems, the concept of resilience requires us to abandon the idea that any water body not conforming to an idealized notion of optimum habitat needs to be fixed. From this new perspective, resource managers must examine variability in current aquatic conditions and establish the large-scale spatial and temporal context of a watershed, historical changes in the system, and potential threats and expectations. The fundamental idea is to characterize variation in natural processes within stream networks and ask where we are, where we want to go, and how we get there in the context of restoring a natural range of habitat conditions for Pacific salmon.

The first step in developing such strategies will be to establish environmental targets that are compatible with natural disturbance and recovery processes. This will include a careful examination of long-term environmental data from nearby areas that are relatively pristine or have been minimally developed, because this information will help set the constraints on what will be possible from a habitat recovery standpoint. The second step will be to assess the current and potential threats to the reestablishment of complex natural habitats. Some of these threats may be addressed by restoration programs, but others, for various reasons, will not, and these will also constrain what is possible. The third step will be to determine if the planning area is sufficiently large to achieve the three criteria for habitat resilience: (1) the capacity to recover from disturbances without intervention, (2) a full range of habitats to support multiple salmon life histories, and (3) ecological connectivity; if so, it will also be necessary to determine when and where restoration techniques should be applied to help maintain these criteria. By performing these steps we can begin to incorporate resilience considerations into habitat management and improve our chances of successfully rehabilitating watersheds for Pacific salmon.

Responses to this article can be read online at: http://www.ecologyandsociety.org/voll4/iss 1/art45/ responses/

\section{Acknowledgments:}

We thank the U.S. Forest Service Pacific Northwest Research Station and the U.S. Geological Survey Forest and Rangeland Ecosystem Science Center for support. Chris Jordan, Rebecca Flitcroft, and two anonymous referees provided constructive suggestions on an earlier draft. Many of our ideas grew out of discussions with colleagues, especially Bruce Rieman, Lee Benda, Kelly Burnett, Steve Wondzell, Bob Bilby, Tom Quinn, Bob Gresswell, Tim Beechie, George Pess, and Bob Naiman. Although we owe much to these fine scientists, any errors in this paper are our own.

\section{LITERATURE CITED}

Augerot, X. 2005. Atlas of Pacific salmon. University of Calilfornia Press, Berkeley, California, USA.

Battin, J., M. W. Wiley, M. H. Ruckelshaus, R. N. Palmer, E. Korb, K. K. Battz, and H. Imaki. 2006. Projected impact of climate change on salmon habitat restoration. Proceedings of the National Academy of Sciences 104:6720-6727.

Baxter, C. V., K. D. Fausch, and W. C. Saunders. 2005. Tangled webs: reciprocal flows of invertebrate prey link streams and riparian zones. Freshwater Biology 50:201-220. 
Beechie, T. J., and S. Bolton. 1999. An approach to restoring salmonid habitat-forming processes in Pacific Northwest watersheds. Fisheries 24:6-15.

Benda, L. E., and T. Dunne. 1997. Stochastic forcing of sediment supply to channel networks from landsliding and debris flows. Water Resources Research 33:2894-2863.

Benda, L. E., D. Miller, J. Sias, D. Martin, R. E. Bilby, C. Veldhuisen, and T. Dunne. 2003. Wood recruitment processes and wood budgeting. Pages 49-74 in S. V. Gregory, K. L. Boyer, and A. M. Gurnell, editors. The ecology and management of wood in world rivers. American Fisheries Society Symposium No. 37. American Fisheries Society, Bethesda, Maryland, USA.

Benda, L., N. L. Poff, D. Miller, T. Dunne, G. Reeves, M. Pollock, and G. Pess. 2004. The network dynamics hypothesis: how river networks structure riverine habitats. BioScience 54:413-427.

Beschta, R. L., R. E. Bilby, G. W. Brown, L. B. Holtby, and T. D. Hofstra. 1987. Stream temperature and aquatic habitat: fisheries and forestry interactions. Pages 191-232 in E. O. Salo and T. W. Cundy, editors. Streamside management: forestry and fishery interactions. Institute of Forest Resources Contribution No. 57. University of Washington, Seattle, Washington, USA.

Bisson, P. A., T. J. Beechie, and G. R. Pess. 2008. Reconciling fisheries with conservation in watersheds: tools for informed decisions. Pages 1865-1880 in J. Nielsen, J. J. Dodson, K. Friedland, T. R. Hamon, J. Musick, and E. Verspoor, editors. Reconciling fisheries with conservation: proceedings of the Fourth World Fisheries Congress. American Fisheries Society Symposium No. 49. American Fisheries Society, Bethesda, Maryland, USA.

Bisson, P.A., and R.E. Bilby. 1998. Organic matter and trophic dynamics. Pages 373-398 in R. J. Naiman and R. E. Bilby, editors. River ecology and management: lessons from the Pacific coastal ecoregion. Springer-Verlag, New York, New York, USA.

Bisson, P. A., C. M. Crisafulli, B. R. Fransen, R. E. Lucas, and C. P. Hawkins. 2005. Responses of fish to the 1980 eruption of Mount St. Helens. Pages 163-182 in V. H. Dale, F. R. Swanson, and C. M. Crisafulli, editors. Ecological responses to the 1980 eruption of Mount St. Helens. Springer-Verlag, New York, New York, USA.

Bisson, P. A., J. A. Lichatowich, W. J. Liss, D. Goodman, C. C. Coutant, L. L. McDonald, D. Lettenmeier, E. J. Loudenslager, and R. N. Williams. 2006. The federal approach to salmon recovery at the millennium. Pages 571-600 in R. N. Williams, editor. Return to the river: restoring salmon to the Columbia River. Elsevier, Burlington, Massachusetts, USA.

Bisson, P. A., G. H. Reeves, R. E. Bilby, and R. J. Naiman. 1997. Watershed management and Pacific salmon: desired future conditions. Pages 447-474 in D. J. Stouder, P. A. Bisson, and R. J. Naiman, editors. Pacific salmon and their ecosystems: status and future options. Chapman and Hall, New York, New York, USA.

Boersma, P. D., S. E. Reichard, and A. N. Van Buren, editors. 2006. Invasive species in the Pacific Northwest. University of Washington Press, Seattle, Washington, USA.

Burnett, K. M., G. H. Reeves, D. J. Miller, S. Clarke, K. Vance-Borland, and K. Christiansen. 2007. Distribution of salmon-habitat potential relative to landscape characteristics and implications for conservation. Ecological Applications 17:66-80.

Dale, V. H., S. Brown, R. A. Haeuber, N. T. Hobbs, N. Huntly, R. J. Naiman, W. E. Riebsame, M. G. Turner, and T. J. Valone. 2000. Ecological principles and guidelines for managing the use of land. Ecological Applications 10:639-670.

Dunham, J. B., A. E. Rosenberger, C. H. Luce, and B. E. Rieman. 2007. Influences of wildfire and channel reorganization on spatial and temporal variation in stream temperature and the distribution of fish and amphibians. Ecosystems 10:335-346.

Dunning, J. B., B. J. Danielson, and H. R. Pulliam. 2002. Ecological processes that affect populations in complex landscapes. Oikos 65:169-175.

Ebersole, J. L., W. J. Liss, and C.A. Frissell. 2003. Thermal heterogeneity, stream channel morphology and salmonid abundance in northeast Oregon streams. Canadian Journal of Fisheries and Aquatic Sciences 60:1266-1280. 
Fausch, K. D., C. E. Torgersen, C. V. Baxter, and H. W. Li. 2002. Landscapes to riverscapes: bridging the gap between research and conservation of stream fishes. BioScience 52:483-498.

Foster, D. R., D. H. Knight, and J. F. Franklin. 1998. Landscape patterns and legacies resulting from large, infrequent forest disturbances. Ecosystems 1:497-510.

Fox, M. J. 2001. A new look at the quantities and volumes of instream wood in forested basins within Washington State. Thesis. University of Washington, Seattle, Washington, USA.

Frissell, C. A., W. J. Liss, R. E. Gresswell, R. K. Nawa, and J. L. Ebersole. 1997. A resource in crisis: changing the measure of salmon management. Pages 411-446 in D. J. Stouder, P. A. Bisson, and R. J. Naiman, editors. Pacific salmon and their ecosystems: status and future options. Chapman and Hall, New York, New York, USA.

Good, T.P., T. K. Harms, and M. H. Ruckelshaus. 2003. Misuse of checklist assessments in endangered species recovery efforts. Conservation Ecology 7(2):12. [online] URL: http://www.consecol. org/vol7/iss2/art12.

Greene, C. M., D. W. Jensen, E. Beamer, G. R. Pess, and A. E. Steel. 2005. Effects of environmental conditions during stream, estuary, and ocean residency on Chinook salmon return rates in the Skagit River, WA. Transactions of the American Fisheries Society 134:1562-1581.

Groot, C., and L. Margolis, editors. 1991. Pacific salmon life histories. University of British Columbia Press, Vancouver, British Columbia, Canada.

Gunderson, L. H. 2000. Ecological resilience-in theory and application. Annual Review of Ecology and Systematics 31:425-439.

Guzy, M. R., C. L. Smith, J. P. Bolte, D. W. Hulse and S, V. Gregory. 2008. Policy research using agent-based modeling to assess future impacts of urban expansion into farmlands and forests. Ecology and Society 13(1):37. [online] URL: http:/ /www.consecol.org/vol13/iss1/art37.

Hastings, K. 2005. Long-term persistence of isolated fish populations in the Alexander
Archipelago. Dissertation. University of Montana, Missoula, Montana, USA.

Healey, M. C. 2009. Resilient salmon, resilient fisheries for British Columbia, Canada. Ecology and Society 14(1): 2. [online] URL: http://www.ecology andsociety.org/vol14/iss1/art2/.

Heckman, C. W. 1999. The encroachment of exotic herbaceous plants into the Olympic National Forest. Northwest Science 73(4):264-276.

Hendry, A. P., and S. C. Stearns, editors. 2003. Evolution illuminated: salmon and their relatives. Oxford University Press, Oxford, UK.

Hilborn, R., T. P. Quinn, D. E. Schindler, and D. E. Rogers. 2003. Biocomplexity and fisheries sustainability. Proceedings of the National Academy of Sciences 100:6564-6568.

Holling, C. S., and G. K. Meffe. 1996. Command and control and the pathology of natural resource management. Conservation Biology 10:328-337.

Hulse, D., and S. V. Gregory. 2004. Integrating resilience into floodplain restoration. Urban Ecosystems 7:295-314.

Independent Scientific Advisory Board (ISAB). 2007. Climate change impacts on Columbia River Basin fish and wildlife. ISAB Climate Change Report ISAB 2007-2. Available online at: http://ww w.nwcouncil.org/library/isab/ISAB\%202007-2\% 20Climate\%20Change.pdf.

Isaak, D. J., R. F. Thurow, B. E. Rieman, and J. B. Dunham. 2007. Chinook salmon use of spawning patches: relative roles of habitat quality, size, and connectivity. Ecological Applications 17: 352-364.

Johnson L. L., G. M. Ylitalo, M. R. Arkoosh, A. N. Kagley, C. Stafford, J. L. Bolton, J. Buzitis, B. F.Anulacion, and T. K. Collier. 2007. Contaminant exposure in outmigrant juvenile salmon from Pacific Northwest estuaries of the United States. Environmental Monitoring and Assessment 124:167-194.

Jonsson, B., and N. Jonsson. 1993. Partial migration: niche shift versus sexual maturation in fishes. Reviews in Fish Biology and Fisheries 2:237-254. 
Karlsson, M., J. Richardson, and P. M. Kiffney. 2005. Modeling organic matter dynamics in headwater streams of south-western British Columbia. Ecological Modeling 183:463-476.

Knudsen,E.E., C. R. Steward, D. D. MacDonald, J. E. Williams, and D. W. Reiser, editors. 2000. Sustainable fisheries management: Pacific salmon. CRC Press, Boca Raton, Florida, USA.

Kocik, J. F., and C. P. Ferreri. 1998. Juvenile production variation in salmonids: population dynamics, habitat, and the role of spatial relationships. Canadian Journal of Fisheries and Aquatic Sciences 55(Supplement 1):191-200.

Lackey, R. T., D. H. Lach, and S. L. Duncan, editors. 2006. Salmon 2100: the future of wild Pacific salmon. American Fisheries Society, Bethesda, Maryland, USA.

Landers, D. H., S. Simonich, D. Jaffe, L. Geiser, D. H. Campbell, A. Schwindt, C. Schreck, M. Kent, W. Hafner, H. E. Taylor, K. Hageman, S. Usenko, L. Ackerman, J. Schrlau, N. Rose, T. Blett, and M. Morrison Erway. 2008. The fate, transport, and ecological impacts of airborne in western national parks, USA. Western Airborne Contaminants Assessment Project Report, Volume I. Available online at: http://www.nature.nps.gov/air/ Studies/air toxics/WACAPreport.cfm.

Lieder, S. A. 1989. Increased straying by adult steelhead, Salmo gairdneri, following the 1980 eruption of Mount St. Helens. Environmental Biology of Fishes 24(3):219-229.

Li, H. W., C. B. Schreck, C. E. Bond, and E. Rexstad. 1987. Factors influencing changes in fish assemblages of Pacific Northwest streams. Pages 193-202 in W. J. Matthews and D. C. Heins, editors. Community and evolutionary ecology of North American stream fishes. University of Oklahoma Press, Norman, Oklahoma, USA.

Lowe, W. H., G. E. Likens, and M. E. Power. 2006. Linking scales in stream ecology. Bioscience 56:591-597.

Lugo, A. E., J. S. Baron, T. P. Frost, T. W. Cundy, and P. Dittburner. 1999. Ecosystem processes and functioning. Pages 219-254 in R. C. Szaro, N. C. Johnson, W. T. Sexton, and A. J. Malick, editors.
Ecological stewardship: a common reference for ecosystem management. Elsevier Science, Oxford, UK.

Mantua, N. J., S. R. Hare, Y. Zhang, J. M. Wallace, and R. C. Francis. 1997. A Pacific interdecadal climate oscillation with impacts on salmon production. Bulletin of the American Meteorological Society 78:1069-1079.

May, C. L., and R. E. Gresswell. 2003. Large wood recruitment and redistribution in headwater streams in the southern Oregon Coast Range, U.S.A. Canadian Journal of Forest Research 33:1352-1362.

Montgomery, D. R. 1999. Process domains and the river continuum. Journal of the American Water Resources Association 35(2):397-410.

Mote, P. W., E. A. Parson, A. F. Hamlet, K. N. Ideker, W. S. Keeton, D. P. Lettenmaier, N. J. Mantua, E. L. Miles, D. W. Peterson, D. L. Peterson, R. Slaughter, and A. K. Snover. 2003. Preparing for climatic change: the water, salmon, and forests of the Pacific Northwest. Climatic Change 61:45-88.

Moyle, P. B., and T. Light. 1996. Biological invasions of fresh water: empirical rules and assembly theory. Biological Conservation 78:149-161.

Moyle, P. B., and G. M. Sato. 1991. On the design of preserves to protect native fishes. Pages 155-169 in W. L. Minckley and J. E. Deacon, editors. Battle against extinction: native fish management in the American west. University of Arizona Press, Tucson, Arizona, USA.

Mull K. E., and M. A. Wilzbach. 2007. Selection of spawning sites by coho salmon in a Northern California stream. North American Journal of Fisheries Management 27(4): 1343-1354.

Naiman, R. J., T. J. Beechie, , L. E. Benda, D. R. Berg, P. A. Bisson, L. H. MacDonald, M. D. O'Conner, P. L.Olson, and E. A. Steel. 1992. Fundamental elements of ecologically healthy watersheds in the Pacific Northwest coastal ecoregion. Pages 127-188 in R. J. Naiman, editor. Watershed management: balancing sustainability and environmental change. Springer-Verlag, New York, New York, USA. 
Naiman, R. J., and R. E. Bilby, editors. 1998. River ecology and management: lessons from the Pacific coastal ecoregion. Springer-Verlag, New York, New York, USA.

Naiman, R. J., R. E. Bilby, D. E. Schindler, and J. M. Helfield. 2002. Pacific salmon, nutrients, and the dynamics of freshwater and riparian ecosystems. Ecosystems 5:399-417.

Naiman, R. J., H. Decamps, and M. E. McClain. 2005. Riparia: ecology, conservation, and management of streamside communities. Academic Press, New York, New York, USA.

National Marine Fisheries Service. 1999. The habitat approach: implementation of Section 7 of the Endangered Species Act for actions affecting the habitat of Pacific anadromous salmonids. National Marine Fisheries Service, Portland, Oregon, USA.

National Research Council. 1996. Upstream: salmon and society in the Pacific Northwest. National Academy Press, Washington, D.C., USA.

Nehlsen, W., J. E. Williams, and J. A. Lichatowich. 1991. Pacific salmon at the crossroads: stocks at risk from California, Oregon, Idaho and Washington. Fisheries 16:4-21.

Northcote, T. G. 1978. Migratory strategies and production in freshwater fishes. Pages 326-359 in S. D. Gerking, editor. Ecology of freshwater fish production. Blackwell Scientific, Oxford, UK.

Pahl-Wostl, C. 1995. The dynamic nature of ecosystems: chaos and order entwined. Wiley, Chichester, UK.

Poff, N. L., J. D. Allen, M. B. Bain, J. R. Karr, K. L Presegaard, B. D. Richter, R. E. Sparks, and J. C. Stromberg. 1997. The natural flow regime. BioScience 47:769-784.

Poff, N. L., M. M. Brinson, and J. W. Day. 2002. Aquatic ecosystems and global climate change. Pew Center on Global Climate Change. Available online at: http://www.pewclimate.org/docUploads/aquatic. pdf.

Poole G. C., J. B. Dunham, U. M. Keenan, S. T. Sauter, D. A. McCullough, C. Mebane, J. C. Lockwood, D. A. Essig, M. P. Hicks, D. J. Sturdevant, E. J. Materna, S. A. Spalding, J.
Risley, and M. Deppman. 2004. The case for regime-based water quality standards. BioScience 54(2):155-161.

Power, M. E., and W.E. Dietrich. 2002. Food webs in river networks. Ecological Research 17:451-471.

Quinn, T. P. 2005. The behavior and ecology of Pacific salmon and trout. University of Washington Press, Seattle, Washington, USA.

Rahel, F. J., and J. D. Olden. 2008. Assessing the effects of climate change on aquatic invasive species. Conservation Biology 22:521-533.

Reeves, G. H., F. H. Everest, and J. R. Sedell. 1993. Diversity of juvenile anadromous salmonid assemblages in coastal Oregon basins with different levels of timber harvest. Transactions of the American Fisheries Society 122:309-317.

Reeves, G. H., L. E. Benda, K. M. Burnett, P. A. Bisson, and J. R. Sedell. 1995. A disturbance-based ecosystem approach to maintaining and restoring freshwater habitats of evolutionarily significant units of anadromous salmonids in the Pacific Northwest. Pages 334-339 in J. L. Nielsen, editor. Evolution and the aquatic ecosystem: defining unique units in population conservation. American Fisheries Society Symposium No. 17. American Fisheries Society, Bethesda, Maryland, USA.

Reeves, G. H., and P. A. Bisson. 2008. Fish and old-growth forests. Chapter 6 in T. Speis and S. Duncan, editors. Old growth in a new world: a Pacific Northwest icon reexamined. Island Press, Washington, D.C., USA.

Richardson, J. S., R. J. Naiman, F. J. Swanson, and D. E. Hibbs. 2005. Riparian communities associated with Pacific Northwest headwater streams: assemblages, processes, and uniqueness. Journal of the American Water Resources Association 41:935-947.

Rieman, B. E., and J. L. Clayton. 1997. Fire and fish: issues of forest health and conservation of native fishes. Fisheries 22(11):6-15.

Rieman, B. E., and J. B. Dunham. 2000. Metapopulations and salmonid fishes: a synthesis of life history patterns and empirical observations. Ecology of Freshwater Fish 9:51-64. 
Rieman, B., J. Dunham, and J. Clayton. 2006. Emerging concepts for management of river ecosystems and challenges to applied integration of physical and biological sciences in the Pacific Northwest, USA. International Journal of River Basin Management 4(2):85-97.

Schlosser, I. J., and P. L. Angermeier. 1995. Spatial variation in demographic processes of lotic fishes: conceptual models, empirical evidence, and implications for conservation. Pages 392-401 in J. L. Nielsen, editor. Evolution and the aquatic ecosystem: defining unique units in population conservation. American Fisheries Society Symposium No. 17. American Fisheries Society, Bethesda, Maryland, USA.

Schtickzelle, N., and T. P. Quinn. 2007. A metapopulation perspective for salmon and other anadromous fish. Fish and Fisheries 8:297-314.

Sedell, J. R., and R. L. Beschta. 1991. Bringing back the "bio" in bioengineering. Pages 160-175 in J. Colt and R. J. White, editors. Fisheries bioengineering symposium. American Fisheries Society Symposium No. 10. American Fisheries Society, Bethesda, Maryland, USA.

Simenstad, C. A., and J. R. Cordell. 2000. Ecological assessment criteria for restoring anadromous salmonid habitat in Pacific Northwest estuaries. Ecological Engineering 15:283-302.

Spies, T. A., K. N. Johnson, K. M. Burnett, J. L. Ohmann, B. C. McComb, G. H Reeves, P. Bettinger, J. D. Kline, and B. Garber-Yonts. 2007. Cumulative ecological and socioeconomic effects of forest policies in coastal Oregon. Ecological Applications 17(1):5-17.

Stockner, J. G., editor. 2003. Nutrients in salmonid ecosystems: sustaining production and biodiversity. American Fisheries Society, Bethesda, Maryland, USA.

Torgersen C. E., D. M. Price, H. W. Li, and B. A. McIntosh. 1999. Multiscale thermal refuge and stream habitat associations of Chinook salmon in northeastern Oregon. Ecological Applications 9:301-319.

Waples, R., T. Beechie, and G. Pess. 2009. Evolutionary history, habitat disturbance regimes, and anthropogenic changes: What do these mean for resilience of Pacific salmon populations? Ecology and Society 14(1): 3. [online] URL: http:// www.ecologyandsociety.org/vol14/iss1/art3.

Waples, R. S., G. R. Pess, and T. Beechie. 2008. Evolutionary history of Pacific salmon in dynamic environments. Evolutionary Applications 1(2):189-206.

Weins, J. A. 2002. Riverine landscapes: taking landscape ecology into the water. Freshwater Biology 47:501-515.

Wellington, T. J., R. J. Hobbs, and S. A. Moore. 2005. Implications of current ecological thinking for biodiversity conservation: a review of the salient issues. Ecology and Society 10(1):15. [online] URL: http://www.ecologyandsociety.org/vol10/iss1/art15

White, S. M., and F. J. Rahel. 2008. Complementation of habitats for Bonneville cutthroat trout in watersheds influenced by beavers, livestock, and drought. Transactions of the American Fisheries Society 137(3):881-894.

Wigington Jr., P. J., J. L. Ebersole, M. E. Colvin, S. G. Leibowitz, B. Miller, B. Hansen, H. R Lavigne, D. White, J. P. Baker, M. R. Church, J. R. Brooks, M. A. Cairns, and J. E. Compton. 2006. Coho salmon dependence on intermittent streams. Frontiers in Ecology and Environment 4 (10):513-518.

Williams, R. N., editor. 2006. Return to the river: restoring salmon to the Columbia River. Elsevier Academic, Amsterdam, The Netherlands.

Williams, R. N., J.A.Stanford, J.A. Lichatowich, W. J. Liss, C. C. Coutant, W. E. McConnaha, R. R. Whitney, P. R. Mundy, P. A. Bisson, and M. S. Powell. 2006. Conclusions and strategies for salmon restoration in the Columbia River Basin. Pages 629-666 in R. N. Williams, editor. Return to the river: restoring salmon to the Columbia River. Elsevier Academic, Amsterdam, The Netherlands.

Wilzbach, M. A., B. C. Harvey, J. L. White, and R. J. Nakamoto. 2005. Effects of riparian canopy opening and salmon carcass addition on the abundance and growth of resident salmonids. Canadian Journal of Fisheries and Aquatic Sciences 62:58-67. 
Wondzell, S. M., M. A. Hemstrom, and P. A. Bisson. 2007. Simulating riparian vegetation and aquatic habitat dynamics in response to natural and anthropogenic disturbance regimes in the Upper Grande Ronde River, Oregon, USA. Landscape and Urban Planning 80:249-267. 